\title{
Method of Express Assessment of Innovative Development of Region Based on "Triple Helix" Model
}

\author{
Nikolay Egorov \\ Scientific-Research Institute of Regional Economy of the North \\ M.K. Ammosov North-Eastern Federal University \\ Yakutsk, Russia \\ ene01@yandex.ru
}

\begin{abstract}
The article provides a method of express assessment of a level of region innovation development based on the use of minimum key indicators of effectiveness of innovation activity patent activity, production of innovation products and state support of innovation activity by an example of subjects of the Far Eastern Federal District. The method is based on an application of a concept of the Triple Helix model. A comparative analysis of results of express assessment according to the author's method is carried out with rating assessments conducted by the National Research University Higher School of Economics, the National Association of Innovations and Development of Information Technologies, and the Association of Innovative Regions of Russia for 2014. Econometric calculations according to the author's method allow making an efficient assessment of a summary integral index of innovation development of the subject of the macroregion according to minimum key statistical indicators of scientific and educational complex, business and the state in the sphere of scientific and innovative activity. The results of calculations according to the author's method show adequacy of the results of the rating express assessment to data of rating assessments of other methods. The main advantage of the proposed method is elimination of subjective factors caused by the use in other methods of the rating assessment of weight coefficients and results of expert assessments. The results of the calculations performed with the use of this author's method can be useful to executive bodies of state power, business structures, scientific and educational institutions for an efficient analysis and making of various organizational and managerial decisions on the development of innovative activity of the region.
\end{abstract}

Keywords-innovation development, patent, innovative product, budgetary expenses for science, Triple helix, econometric calculations.

\section{INTRODUCTION}

Effectiveness of implementation of innovation policy largely depends on a system of evaluation indicators, which are the basis for determining innovation activity and monitoring its development. In this regard, one of the main tasks in this direction is formation of a complex of indicators for the assessment of the level of innovation development of the region, taking into account necessary opportunities and resources. However, in the practice of management, universal approaches to the assessment of the innovative level of regional development have not been developed, which hinders the adequate assessment of effectiveness of state innovation policy at federal and regional levels, and efficiency of spending budget funds [1]. There are different opinions and judgments of Russian researchers on this issue. In general, a conducted analysis of literature shows that the main reason of existence of a variety of methods is absence of a unified methodological development for selecting indicators that characterize the innovation potential. The assessments of the innovative potential of the region are made mainly on the basis of expert survey data, which introduces subjectivity of indicators that affect inaccuracies in the results of the assessment.

In Russia, the use of direct indicators is difficult because of low reliability of innovation activity statistics and a lack of many indicators from a regional point of view. Hence a problem of a universal system for determining the innovation potential of the regions remains topical [2]. The choice of indicators for the assessment of innovation activity in the regions is quite relative and faces methodological difficulties, caused by both imperfection of statistical service and methodological problems [3]. Certain difficulties are also associated with backwardness of modern Russian innovation statistics, which, in view of very low interest to a problem of activation of innovation activity on the part of the country's leadership, has not practically developed in recent years. In particular, state registration of activity of objects of innovative infrastructure has not been established so far. As a result, today there is no exact information even about their quantity, and even more so regularly collected official data, which allow evaluating objectively the effectiveness of their work (and in fact, state money is invested in the development of innovation infrastructure) [4]. At the same time, the most significant shortcoming of the proposed methods for the comparative evaluation of the regions of the Russian Federation according to the level of innovation development is their weak linkage with current problems of innovative and technological development of Russia, as well as a lack of clear goal-setting, that is, an idea about for what purposes and how the results can be used in solving practical issues of state management of innovation activity, taking into account technologies of use of innovations developed in the world practice to strengthen prerequisites for successful socio-economic growth of the territory [5].

According to A. Lisina [6], the main problem in determining the level of innovation development of the region is the lack of a scientifically grounded necessary and sufficient number of indicators for assessing the effectiveness of regional innovation processes. An analysis of requirements for management shows that in order to improve the effectiveness of administrative decisions in the innovation sphere, it is necessary to identify 15-20 indicators, on the basis of which the level of innovative development of the region is calculated. 
In the opinion of E. Fedorova, 6 groups of factors are sufficient for quantitative characterization of factors having direct or indirect influence on the development of innovation activity in the subjects of the Russian Federation: a factor of influence of human capital; an infrastructure factor; an "Innovative government" factor; an intellectual result; a socio-economic effect; a factor of industry specialization [7]. On the other hand, in a study with a specific aim of a particular object, even with simple tools and limited information, it is possible to obtain meaningful results useful for elaboration of elements of economic policy [8]. According to the opinion of the authors of [9], the use of a significant number of indicators makes the ratings difficult to verify, and also too cumbersome to be used as a tool for strategic management. It is necessary to simplify them and bring into correspondence with target indicators of regional strategies for "smart" specialization.

\section{KEY INDICATORS OF EFFECTIVENESS OF INNOVATIVE ACTIVITY}

Based on the above statements, a simplified system of key indicators characterizing the effectiveness of innovation activity (EIA) of the scientific and educational complex (SEC), the business and the state (a triad) can be used to conduct the express assessment of the level of innovation development of region (IDR).

Within the framework of the concept of the Triple Helix model, SEC acts as a generator of knowledge and innovative ideas, the owner of an intellectual property object, in commercialization of which are interested, on the one hand, the business (making a profit) and, on the other hand, the state (the policy of support of innovation activity). Therefore, final practical results of activity of SEC should be developed, as well as innovations important for needs of innovative business. According to $\mathrm{Yu}$. Smirnov [10], inventive activity makes it possible to analyze a correspondence of the level of development of innovation potential of a need of the real sector for technological innovations in two aspects: the level of inventive activity in the country and the level of practical use of results of innovation activity. In this regard, a key indicator of the effectiveness of scientific research and development of the SEC is a number of issued patents of Russia for inventions, useful models and industrial samples per 1000 people of economically active population (EAP) (notation $\mathbf{I}_{1}$ ). Patent statistics is a unique source for an analysis of processes related to technological progress; therefore, it should become one of possible variants of the system of indicators in the sphere of science and innovation in the regions of Russia [11]. Inventive efficiency can be defined as an ability of the region to create new technologies with given values of human capital and R\&D costs and to use it when assessing the effectiveness of the regional innovation system [12].

The effectiveness of innovation activity of the production process (the business) is mainly determined by a statistical indicator "a relative share of innovative goods, work, services in a total volume of shipped goods, performed work, services" $\left(\mathbf{I}_{2}\right)$, and the effectiveness of state support of innovation activity is "a relative share of budget expenses for scientific studies in expenses of consolidated budget of the subject of the Russian Federation" ( $\left.\mathbf{I}_{3}\right)$. Let us note that the given names of indicators are based on a system of indicators of the Russian regional innovation index of the National Research University Higher School of Economics (NRU HSE) [13]. For the analysis, official statistical data of the Russian Federal State Statistics Service, the Russian Federal Service for Intellectual Property and the Federal Treasury of Russia are used.

\section{RESULTS OF EXPRESS ASSESSMENT}

In principle, the key indicators listed above characterize the effectiveness of a contribution of participants in the triad of the "Triple Helix" model (SEC, the business, the state) $[14,15]$ to the overall IDR and allow conducting an efficient express assessment of the summary index of IDR. As noted in [16], a concrete application of the Triple Helix model in quantitative assessments was not entirely obvious, primarily due to complexity of modelled relationships. If in physical media, measurements of physical quantities do not cause fundamental difficulties, then measurements in complex socio-economic environments are characterized by considerable difficulties. Therefore, factual material - numerical data and their statistical analysis for all three components of the Triple Helix - is of great importance.

Within the framework of representation of the triad relationships in the Triple-helix model, the summary index of the IDR level can be represented as a composite integral contribution of the mentioned indicators of the triad in the form of expression:

$$
I=\sqrt{l_{1}^{2}+l_{2}^{2}+l^{2}} .
$$

Results of values of indicators normalized to one in the Far Eastern Federal District (FEFD) for 2014 are presented in Table I.

TABLE I. DISTRIBUTION OF KEY INDICATORS OF EIA ACCORDING TO SUBJECTS OF FEFD FOR 2014

\begin{tabular}{lrlll}
\hline \multicolumn{1}{c}{ Region of FEFD } & $\begin{array}{c}\text { Number of EAP, } \\
\text { thousands of } \\
\text { people. }\end{array}$ & $\begin{array}{l}\mathbf{I}_{\mathbf{1}} \\
\text { un. }\end{array}$ & $\begin{array}{c}\mathbf{I}_{\mathbf{2}}, \\
\%\end{array}$ & $\begin{array}{c}\mathbf{I}_{\mathbf{3}}, \\
\%\end{array}$ \\
\hline $\begin{array}{l}\text { Republic of Sakha } \\
\text { (Yakutia) }\end{array}$ & 502.9 & 0.66 & 0.03 & 1.00 \\
Kamchatskiy Krai & 188.8 & 0.22 & 0.02 & 0.02 \\
Primorsky Krai & 1059.7 & 0.77 & 0.01 & 0.03 \\
Khabarovsk Krai & 744.6 & 0.96 & 0.21 & 0.58 \\
Amur Oblast & 421.8 & 1.00 & 0.08 & 0.03 \\
Magadanskaya Region & 94.1 & 0.27 & 0.00 & 0.00 \\
Sakhalin Oblast & 281.5 & 0.07 & 1.00 & 0.05 \\
Jewish Autonomous Oblast & 85.7 & 0.04 & 0.01 & 0.00 \\
Chukotskiy Autonomous & 33.3 & 0.00 & 0.00 & 0.00 \\
Region & & & & \\
\hline
\end{tabular}

It can be seen from Table I that the patent activity in the considered year is at a high level in Amur Oblast (an absolute value is 0.31 units per 1000 people of EAN), Khabarovsk Krai (0.30 units), Primorsky Krai (0.24) and the Republic of Sakha 
(Yakutia) (0.21 units). According to the value of the business indicator $\left(\boldsymbol{I}_{2}\right)$, Sakhalin Oblast $(60.1 \%)$ is in a leading position with a large margin from other subjects, followed by Khabarovsk Krai (12.5\%) and Amur Oblast (4.7\%). A relatively high indicator of Sakhalin Oblast in terms of the relative share of innovative goods, work, services in the total volume of shipped goods and the performed work is apparently due to significant technological upgrades of production processes in the oil and gas industry. The Republic of Sakha (Yakutia) (184.8 million rubles) and Khabarovsk Krai (39.4 million rubles) occupy the first two places according to the level of budget expenses of the subject of the FEFD for the scientific studies, and it should be noted that the financing of fundamental studies is carried out only in the Republic of Sakha (Yakutia) (116.1 million rubles). Naturally, it is logical that the regional leaders listed above make the main contribution to the overall IDR of the macroregion, which is confirmed by the histogram shown below (Fig. 1).

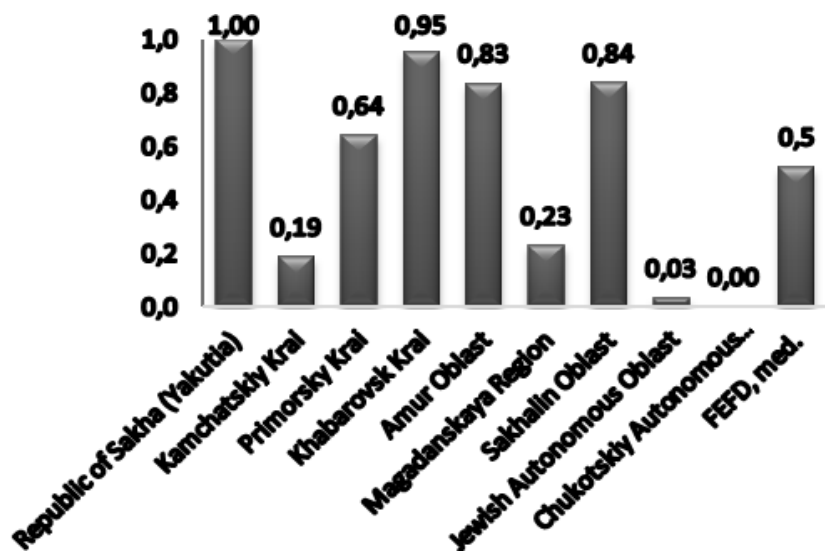

Fig. 1. Distribution of level of innovative development of subjects of FEFD in 2014

For the assessment of adequacy of results of evaluation using this method, it is necessary to compare them with the results of the rating performed by other methods. In the modern domestic scientific literature various methods of rating assessments of IDR level are offered. For example, the rating of the Institute for Statistical Studies and Economics of Knowledge of the National Research University of the Higher School of Economics is based on an original system of quantitative and qualitative indicators of innovative development of regions. The index is formed from a system of 37 indicators of a Russian regional innovation index, grouped into four thematic blocks and providing a possibility of calculation of corresponding subindexes [13]. For the analysis of innovative activity of the regions, the National Association of Innovations and Information Technology Development (NAIITD) uses a system of quantitative innovation indicators, developed on the basis of the European Innovation Scoreboard (EIS) rating [17] for the assessment of the level of innovation development of European countries and adapted taking into account national specificity and possibilities to search for various statistical data [18]. The rating of innovative regions for monitoring and management purposes was developed by the Association of Innovative Regions of Russia (AIRR) in 2012 jointly with the Ministry of Economic Development of the Russian Federation with participation of representatives of regional administrations. The rating 2015-1.0 includes 23 indicators [19].

Table II presents the results of comparison of rating assessments of NRU HSE, NAIITD, AIRR, and the author's method on the basis of the "Triple Helix" model for the subjects of the Far Eastern Federal District for 2014. The place in the rating of regions is indicated in parentheses.

TABLE II. RATING ASSESSMENTS OF LEVEL OF IDR OF FEFD

\begin{tabular}{|c|c|c|c|c|}
\hline Region & $\begin{array}{l}\text { NRU } \\
\text { HSE }\end{array}$ & NAIITD & AIRR & $\begin{array}{l}\text { Triple } \\
\text { Helix }\end{array}$ \\
\hline $\begin{array}{l}\text { Republic of Sakha } \\
\text { (Yakutia) }\end{array}$ & $0.330(2)$ & $0.010(4)$ & $0.320(6)$ & $1.201(1)$ \\
\hline Kamchatskiy Krai & $0.310(5)$ & $0.013(3)$ & $0.380(3)$ & $0.768(5)$ \\
\hline Primorsky Krai & $0.450(1)$ & $0.084(1)$ & $0.420(2)$ & $1.142(2)$ \\
\hline Khabarovsk Krai & $0.291(6)$ & $0.002(8)$ & $0.270(7)$ & $1.002(4)$ \\
\hline Amur Oblast & $0.261(7)$ & $0.023(2)$ & $0.360(4)$ & $0.223(7)$ \\
\hline $\begin{array}{l}\text { Magadanskaya } \\
\text { Region }\end{array}$ & $0.325(3)$ & $0.007(6)$ & $0.440(1)$ & $0.273(6)$ \\
\hline Sakhalin Oblast & $0.316(4)$ & $0.007(5)$ & $0.340(5)$ & $1.004(3)$ \\
\hline $\begin{array}{l}\text { Jewish Autonomous } \\
\text { Oblast } \\
\text { Chukotskiy }\end{array}$ & $0.159(9)$ & $0.002(9)$ & $0.210(9)$ & $0.039(8)$ \\
\hline $\begin{array}{l}\text { Autonomous } \\
\text { Region }\end{array}$ & $0.237(8)$ & $0.003(7)$ & $0.270(8)$ & $0.000(9)$ \\
\hline
\end{tabular}

Source: compiled by the author based on the results of processing the materials of NRU HSE, NAIITD, AIRR and the calculation according to the author's method [20, 21].

The results given in Table II of the comparative express assessment according to the author's method show the adequacy of the results of this method in comparison with the results of other methods. It can be seen that the Republic of Sakha (Yakutia) and Khabarovsk Krai occupy an unquestionable leadership position in the results of the rating of NRU HSE and the author's method. The third place for the year under consideration is occupied by Sakhalin Oblast. As the analysis of statistical data shows, in Sakhalin Oblast the average value of the relative share of innovative goods, work, and services in the total volume of shipped goods, performed work, and services for the period of 2010-2014 is significantly higher than the other subjects of the Far Eastern Federal District $(45.8 \%)$. The closest values of this indicator are only 7.1\% (Khabarovsk Krai) and 5.8\% (Magadanskaya Region). This fact is apparently due to taking into account in the indicator $\mathrm{I}_{2}$ facts about the technological upgrade in the sphere of the oil and gas industry, which is the basic branch of the regional economy for the Sakhalin Oblast.

The method of the express assessment of the level of IDR, developed by the author, also makes it possible to evaluate and determine the contribution of each participant of the Triple Helix model to the overall innovative development of the economy of the studied subject of the economy. As an example, Fig. 2 shows distribution of the contribution of the scientific and educational complex, the business and the state to the overall innovative development of the Far East Federal 
District for 2014. It can be seen that a relatively high indicator of intellectual potential $(58.6 \%)$ and a low level of state support of the innovation activity $(19.8 \%)$ do not provide a high level of practical business results to increase the output of innovative products to the market $(21.6 \%)$. This shows that the budgetary expenditures for research and development produced by the regions are insufficient or they are inefficiently used to enhance the patent activity of the scientific and educational complex and the production of innovative products by the business. It should also be kept in mind the fact that the developed and adopted normative legal and legislative acts in the sphere of scientific, technical, and innovation policy of the region do not immediately affect the development of the innovation process on the whole.

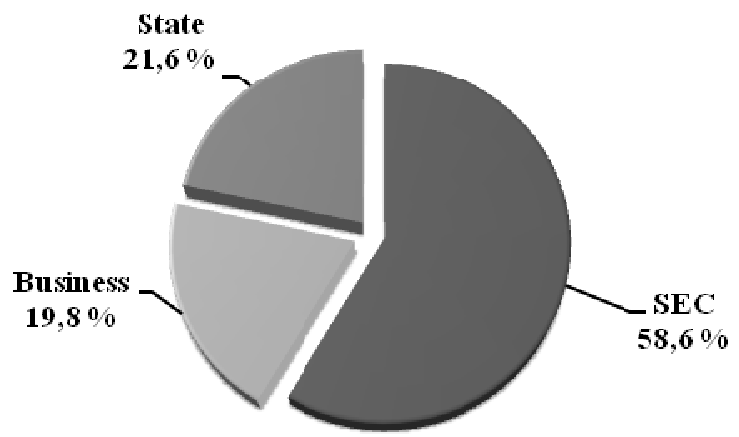

Fig. 2. Distribution of contribution of key indicators of triad to overal innovation development of Far East Federal District for 2014

It should be noted that an adequate analysis of calculation results using this method requires necessity of coordination of used key indicators of the triad with representatives of the subject of the economy (an innovation cluster, a manufacturing enterprise, etc.), which will allow heads of organizations to make appropriate organizational, administrative and other necessary decisions on further strategic planning and development of their business.

A promising direction of further studies of this topic is related with the use of the stated author's method to a solution of questions of assessment of influence of innovation on the society, which provides for an expansion of the system of indicators by social indicators of human vital activity.

\section{CONCLUSION}

In general, the comparative analysis of the given results shows that the key indicators of innovation activity, selected for the analysis and assessment, adequately reflect the real picture of the current state of innovation development of the subjects of the Far Eastern Federal District, on the basis of which certain scientific and practical recommendations for making various managerial decisions can be formulated. The stated method will allow improving the level and quality of strategic planning and management of the development of the innovative economy of macroregions. The main advantage of the proposed method of express assessment is the elimination of subjective factors caused by the use in the other methods of the rating assessment of weight coefficients and the results of expert assessments, as well as the efficiency of the assessment of the level of IRD and the effectiveness of the contribution of participants of the triad according to their key statistical indicators in the sphere of scientific and innovative activity.

The results of the work can be useful to the executive bodies of state power, business structures, scientific and educational organizations of the federal districts for the analysis and forecast of the formation and development of the innovation system, strategies and programs of development. A promising direction of further studies is related to an application of the stated method for a solution of questions of assessment of influence of innovations on society, which stipulates addition of social indicators of the population to the key indicators.

\section{Acknowledgment}

The article was prepared on the results of the project "Assessment, the main trends in change of the natural and socio-economic status, human development of the Arctic Economic Zone of the Republic of Sakha (Yakutia)" of the Program of Integrated Research in the Republic of Sakha (Yakutia) aimed at developing its productive forces and social sphere in 2016-2020 years».

\section{References}

[1] O.A. Vorobyova, O.D. Golovina, Yu.N. Polyakov, "Methodological questions of assessment of innovation development of industriallyoriented region," Bulletin of Udmurt University. Economics and Law, Vol. 1, pp. 24-29, 2014.

[2] V.I. Menshchikova, A.I. Ermakov, "Methods of assessment of innovative potential of region: Essence, application features, shortcomings," Socioeconomic phenomena and processes, No. 10 (032), pp. 127-136, 2011.

[3] N.N. Volkova, E.I. Romanyuk, "Evaluation of innovation activity in regions of Russia," Federalism, No. 1, pp. 161-178, 2012.

[4] I.M. Golova, "Innovative competitiveness of the Russian regions," Economy of Region, No. 3, pp. 294-311, 2015. doi: 10.17059.2015-3-24.

[5] I.M. Golova, "Methodological problems in studies of regional development priorities of innovation," Economy of Region, No. 2, pp. 145-156, 2013.

[6] A.N. Lisina, "Method of assessment of the level of innovation development of the region," Bulletin of NSU. Series: Socio-economic sciences, Vol. 12, Issue 1, pp. 115-126, 2012.

[7] E.V. Fedorova, "Perfection of methodical approaches to evaluation of innovation activity (on example of regions of the Russian Federation)," Author's abstract of dis. for degree of Cand. of Econ. Sciences, National Research University of Information Technologies, Mechanics and Optics. St. Petersburg, 2013.

[8] S.V. Kazantsev, "Assessment of potential and scales of innovation activity in subjects of Russian Federation," Innovations, No. 8, pp. 36-45, 2012.

[9] V.A. Barinova, S.P. Zemtsov," Rating the Innovative Development of the Russian Regions: Why Does Russia Need a New Method?" Bulletin of the Volga Region Institute of Administration, No. 6(57), pp. 110-115, 2016.

[10] Yu.G. Smirnov, "Patent logistic system as basis of innovation system," Innovations, No. 4, pp. 65-71, 2014.

[11] E.L. Domnich, "Patent statistics as measure of economy of science and innovations in regions of Russia," Innovations, No. 5, Pp. 92-95, 2013.

[12] S.P. Zemtsov, V.L. Baburin, "How to evaluate effectiveness of regional innovation systems in Russia?" Innovations, No. 2, C. 60-66, 2017.

[13] "Rating of innovative development of subjects of Russian Federation," Vol. 4. Moscow: NRU HSE, 2016. URL: https://issek.hse.ru/data/2016/06/28/1115847925/RIR\% 202016.pdf. 
[14] H. Etzkowitz, "Innovation in innovation: the triple helix of universityindustry-government relations," Social Science Information," No. 42, pp. 293-337, 2003.

[15] H. Etzkowitz, L. Leydesdorff, "The dynamics of innovation: from National Systems and "Mode 2" to a Triple Helix of universityindustry-government relations," Research Policy," Vol. 29, No. 2-3. pp. 109-123, 2000.

[16] P.N. Drobot, D.A. Drobot, N.G. Teterkina, "Problem of quantitative analysis in model of triple helix", Innovation-2010, pp. 305-310, April 2010 [VI All-Russian scientific-practical conf., 2010].

[17] "European Innovation Scoreboard," URL: http://www.proinnoeurope.eu/ page/european-innovation-scoreboard-2009.

[18] "National Association of Innovations and Information Technology Development," URL: http://www.nair-it.ru/news/31.07.2015/461.

[19] "Rating of innovation regions for monitoring and management purposes," URL: http://i-regions.org/files/file_47.pdf.

[20] N.E. Egorov, "Method of assessment of level of contribution of triple helix participants in innovative development of economy subject," Helice, Vol. 4, Issue 2, pp. 27-31. 2015. http://doi.org/10.17686/sced_rusnauka_2015-1323.

[21] N.E. Egorov, A.V. Babkin, G.S. Kovrov, S.V. Muraveva, "Comparative Assessment of Innovative Activity of Region's Economy Actors on the Basis of the Triple Helix Model," Procedia - Social and Behavioral Sciences, No. 207, Pp. 816-823. 2015. doi 10.1016/j.sbspro.2015.10.172. 